\title{
Effects of mussel farms on the benthic nitrogen cycle on the Swedish west coast
}

\author{
Marita Sundstein Carlsson ${ }^{1,2, *}$, Pia Engström ${ }^{3}$, Odd Lindahl ${ }^{4}$, Lars Ljungqvist ${ }^{5}$, \\ Jens Kjerulf Petersen ${ }^{6}$, Linda Svanberg ${ }^{7}$, Marianne Holmer ${ }^{2}$ \\ ${ }^{1}$ Department of Marine Ecology, National Environmental Research Institute, Aarhus University, 4000 Roskilde, Denmark \\ ${ }^{2}$ Institute of Biology, University of Southern Denmark, 5230 Odense M, Denmark \\ ${ }^{3}$ Civil and Environmental Engineering, Chalmers University of Technology, 41296 Gothenburg, Sweden \\ ${ }^{4}$ The Royal Swedish Academy of Sciences, 45034 Fiskebäckskil, Sweden \\ ${ }^{5}$ Sven Lovén Centre for Marine Sciences, and ${ }^{7}$ Department of Marine Ecology, University of Gothenburg, \\ 45034 Fiskebäckskil, Sweden \\ ${ }^{6}$ Danish Shellfish Centre, 7900 Nykøbing M, Denmark
}

\begin{abstract}
The biogeochemical impact of 3 long-line mussel farms (M1, M2 and M3) in Lysekil, Sweden, was investigated from before farm establishment until $1.5 \mathrm{yr}$ after operation had begun. Sedimentation, benthic N flux, total oxygen uptake (TOU) and sulfate reduction rate (SRR) were all significantly increased below the mussel lines at all 3 farms. Effects of increased sedimentation rates were revealed by sediment profile imaging and were highest at Stn M2. These effects increased significantly with time of farm operation, indicating the accumulation of organic matter within sediments over time. Furthermore, more total particulate organic $\mathrm{N}$ deposited at farm stations was recycled into the water column compared to at reference stations ( $\sim 5$ versus $\sim 13 \%$ ), indicating an increased release of dissolved inorganic $\mathrm{N}$ from sediment below the mussel farms. At one station (M2) with the highest increase in sedimentation rate, denitrification seemed inhibited, while at another station (M3), with a less pronounced increase in sedimentation rate, denitrification was in fact stimulated, accounting for $13 \%$ of total sediment $\mathrm{N}$ removal. Calculations based on estimated values of $\mathrm{N}$ removal through mussel harvest and direct measurements of $\mathrm{N}$ input through changes in sedimentation, $\mathrm{N}$ regeneration from sediment to the water column through benthic fluxes and changes in denitrification showed, in all cases, a net removal of $\mathrm{N}$ from the system, as only 26 to $40 \%$ of the total amount of harvested $\mathrm{N}$ had been added to the sediments during the growth period.
\end{abstract}

KEY WORDS: Mussel farm $\cdot$ Benthic mineralization $\cdot$ Nitrogen $\cdot$ Denitrification

\section{INTRODUCTION}

Mussel aquaculture is an internationally expanding industry, and also currently increasing along the Scandinavian coasts (Smaal 2002). The conditions for cultivating blue mussels Mytilus edulis in off-bottom farms are favourable due to the plentiful supply of mussel larvae and plankton in this area. Mussel farms have the potential to permanently remove particle-bound nitrogen $(\mathrm{N})$ and phosphorus $(\mathrm{P})$ from the water column, thereby improving water quality in eutrophic areas (Lindahl \& Kollberg 2009). Eutrophication as a result of excess nutrient supply is widespread in Scandinavia, as it is in other coastal areas around the world (Diaz \& Rosenberg 2008). Although several international agreements (North Sea and OSPAR) have outlined goals to reduce anthropogenic $\mathrm{N}$ and $\mathrm{P}$ emissions to the sea, these remain unfullfilled (Rosenberg 1990, Anonymous 2001). Blue mussels could have the ability to reduce 
nutrient levels in coastal waters, as they feed on particles suspended in the water column and thereby remove nutrients bound in primary production. Indeed, the farming of filter-feeding mussels has been suggested as a sustainable method for producing food of high nutritional value, whilst simultaneously recycling nutrients from sea to land (Edebo et al. 2000, Lindahl et al. 2005).

Mussel farms have been established in the village of Lysekil on the Swedish west coast to remove excess nitrogen released by the village's sewage treatment plant. Nearly $40 \mathrm{t} \mathrm{N} \mathrm{yr}^{-1}$ is discharged from the treatment plant, and, following European Union (EU) regulations, $70 \%$ of this $\mathrm{N}$ release must now be removed. Harvest of $1 \mathrm{t}$ of blue mussels is estimated to remove 6 to $10 \mathrm{~kg} \mathrm{~N}$ from the ocean (Petersen \& Loo 2004) based on the total $\mathrm{N}$ content of mussel shell and meat. The removal of $28 \mathrm{t} \mathrm{N} \mathrm{yr}^{-1}$ (70\% of $40 \mathrm{t}$ ) to compensate for the input from the sewage treatment plant would require an annual harvest of minimum $2800 \mathrm{t}$ of mussel biomass. In Lysekil, 20 units (with each unit producing 140 to $180 \mathrm{t}$ of mussels in $18 \mathrm{mo}$; Lindahl et al. 2005) must be harvested annually to meet this requirement. With the ultimate aim of removing $100 \%$ of the nitrogen discharge, 35 longline farm units were established in the town in 2005.

The environmental impact of long-line mussel farming in Scandinavia was reviewed by Petersen \& Loo (2004), who found a general lack of knowledge regarding the effect of mussel farms on the cycling of elements (including $\mathrm{N}$ and $\mathrm{P}$ ) in the underlying sediments. Even though the harvest of mussels represents an export of nutrients from coastal waters, mussel farming also increases nutrient loading of underlying sediments due to the sedimentation of mussel biodeposits (Hartstein \& Stevens 2005). The biodeposits of suspension-feeding bivalves can be rich in carbon (C) and N (Kautsky \& Evans 1987), and sedimentation rates 3 to 5 times higher under mussel farms compared to outside reference sites have been reported (Hartstein \& Stevens 2005, Carlsson et al. 2009). Organic enrichment of underlying sediment may lead to increased mineralization of organic matter, altering sediment biogeochemistry and potentially affecting benthic community structure (Carlsson et al. 2009).

One of the element cycles affected by increased sedimentation is N cycling (Kaspar et al. 1985, Christensen et al. 2003). Increased input of organic matter to the sediment provides substrate for heterotrophic denitrifiers which oxidize organic carbon with nitrate. This can stimulate $\mathrm{N}_{2}$ production and enhance the natural removal of bioavailable nitrogen
(Laursen \& Seitzinger 2002). However, at more extreme levels of organic matter input competition for electron acceptors and stimulated sulfate reduction creating sulfidic environments often negatively affect denitrification, as found below fish farms (Christensen et al. 2000, Sayama 2001). When marine sediments become sulfidic, nitrogen mineralization pathways can shift from net nitrogen removal through denitrification or anammox to production of ammonium $\left(\mathrm{NH}_{4}^{+}\right)$via dissimilatory nitrate reduction (DNRA). Such shifts in nitrate reduction pathways have been reported from several organically enriched sites, including in Tokyo Bay (Sayama 2001) and below fish farms (Christensen et al. 2000). When nitrogen mineralization is dominated by $\mathrm{NH}_{4}{ }^{+}$production, a larger proportion of organic nitrogen is recycled back into the water column and becomes available for pelagic primary production. A shift from denitrification to DNRA as the major nitrate-reducing pathway therefore results in enhanced retention of nitrogen in the coastal environment as dissolved inorganic $\mathrm{N}$ rather than loss as $\mathrm{N}_{2}$ to the atmosphere. High sedimentation resulting from mussel production decreased denitrification at a mussel farm in New Zealand, and only $2 \%$ of the $\mathrm{N}$ input from the farm was removed through $\mathrm{N}_{2}$ production (Christensen et al. 2003). At the same time $\mathrm{NH}_{4}{ }^{+}$effluxes from the sediment were stimulated, increasing nutrient availability in the water column. Under such a scenario, the predicted $\mathrm{N}$ removal estimated through mussel harvest may be overestimated and total $\mathrm{N}$ budgets should be revised.

The environmental impact of long-line mussel farms in the Lysekil area was investigated with the specific aims of determining (1) how these farms affect benthic $\mathrm{N}$ mineralization and estimating (2) whether the established farms in the area potentially fulfil the request of reducing $\sim 70 \%$ of the $\mathrm{N}$ input to the area. This was done by measuring $\mathrm{N}$ sedimentation rates, fluxes of dissolved organic $\mathrm{N}(\mathrm{DON})$, dissolved inorganic $\mathrm{N}\left(\mathrm{NH}_{4}{ }^{+}, \mathrm{NO}_{2}{ }^{-}+\mathrm{NO}_{3}{ }^{-}\right)$and denitrification rates in the underlying sediments and at a reference station. Additionally, pools of organic $\mathrm{N}$ in the surface sediment, total benthic oxygen uptake (TOU) and sulfate reduction rates (SRR) were analyzed. Based on sediment flux measurements and denitrification rates, $\mathrm{N}$ input versus $\mathrm{N}$ removal in the underlying sediment was estimated in order to provide insight into $\mathrm{N}$ cycling in mussel farm sediment. A similar study investigating the environmental impact of mussel farms has already been performed in Limfjorden, where eutrophication has a significant influence on sediment mineralization rates (Carlsson 
et al. 2009). However, their study provided no detailed insight into $\mathrm{N}$ cycling. Furthermore, the Limfjorden site differs from the Lysekil area in several ways, including shallower water depth, suggesting a less intensive benthic impact in Lysekil.

\section{MATERIALS AND METHODS}

\section{Field sampling}

The Lysekil sampling site is located in the Skagerrak Strait on the Swedish west coast, with moderate exposure to the open ocean (Fig. 1). Three mussel farms, M1, M2 and M3, with a water depth of 18.5, 19 and $18.5 \mathrm{~m}$, respectively, were visited 3 times. The first visit was in September 2005 (Sep05), 2 mo after the farms were established in July 2005, followed by a second visit in May 2006 (May06) and a third in September 2006 (Sep06). M1 and M3 were located relatively close to each other at a distance of $600 \mathrm{~m}$, while M2 was located approximately $2500 \mathrm{~m}$ further to the southeast. M2 was more sheltered compared to M1 and M3, due to their exposure to the northeast (Fig. 1). Each farm corresponded to 1 unit (1 ha) of the 20 established farms in the area. Horizontal $200 \mathrm{~m}$ long-lines, attached to buoys, were placed $0.5 \mathrm{~m}$ below the surface. Vertical mussel lines $(10 \mathrm{~m})$ were attached to the long-lines $0.5 \mathrm{~m}$ apart. Mussel biomass was estimated to be approximately $250 \mathrm{t}$ at harvest (in Sep06 after the last visit). Average individual growth

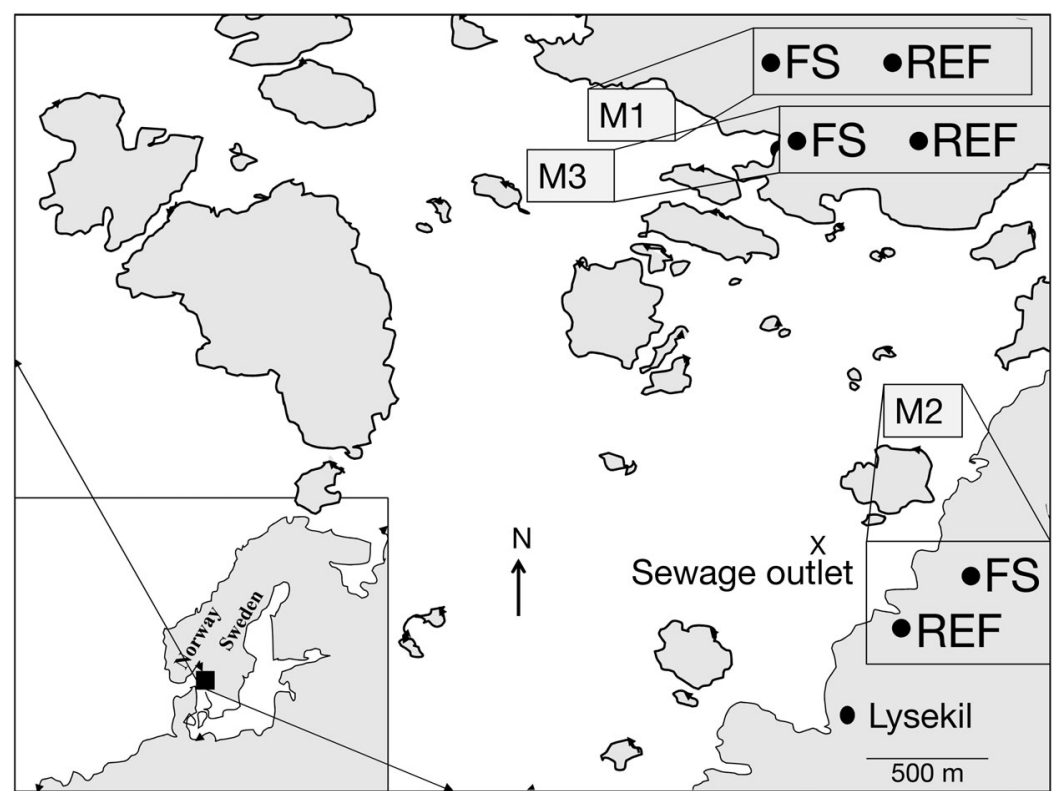

Fig. 1. Map of the Lysekil area with mussel farms M1, M2 and M3. FS: farm station, REF: reference station of the mussels was $45 \mathrm{~mm}$ after the first year, with the mussels attaining 50 to $60 \mathrm{~mm}$ in length by the time of harvest. From Scuba dives carried out in Sep05 and observations from ship made during each sampling occasion, biomass at M3 was estimated to be lower in comparison to the other farms, as approximately $25 \%$ of the growth lines were without mussels.

Sediment samples were collected at a farm station (FS) situated in between mussel lines in the centre of the farms and at a reference station (REF) $100 \mathrm{~m}$ outside the farm. FSs and REFs were thus located relatively close, and, from examinations before mussel farming was initiated, the locations were considered to be similar. In addition to the 3 visits to the farms, sediment cores were collected at FS in May05 (2 mo before the farms were established).

Six sediment cores for measurement of nutrient fluxes, denitrification and total oxygen uptake were collected on each sampling occasion at each station by deploying an Olausen box-corer $(30 \times 30 \mathrm{~cm})$ 6 times. From each box-core retrieval 1 core was subsampled in $30 \mathrm{~cm}$ long Plexiglas liners (i.d. $10 \mathrm{~cm}$ ). Three smaller $20 \mathrm{~cm}$ long (i.d. $2.6 \mathrm{~cm}$ ) liners equipped with silicone-filled ports were also sub-sampled from the box-corer and used for measuring sulfate reduction rates. Sediment cores were capped and stored on deck in the shade until arrival at the laboratory (max. $8 \mathrm{~h}$ ). Surface sediment (0 to $2 \mathrm{~cm}$ ) for anoxic sediment incubation was collected from the Olausen box-corer and stored in a closed plastic container on deck. Bottom water samples for in situ nutrients $\left(\mathrm{NH}_{4}{ }^{+}, \mathrm{NO}_{3}{ }^{-}+\right.$ $\mathrm{NO}_{2}{ }^{-}$and $\mathrm{HPO}_{3}{ }^{2-}$ ) and $\mathrm{O}_{2}$ concentration measurements were collected in Niskin bottles $(\mathrm{n}=3)$, specially designed for bottom water sampling.

In September 2006, sedimentation rates of particulate organic carbon (POC) and particulate organic nitrogen (PON) were measured at FS and REF at both M2 and M3 using single cylinder sediment traps $(53 \mathrm{~cm}$ height, $8 \mathrm{~cm}$ depth, aspect ratio $=6, n=3$ ). Sediment traps were suspended from a floating board moored to the bottom of 3 consecutive mussel lines (1 line trap $\left.^{-1}\right)$ at FS at a water depth of $10 \mathrm{~m}$. At REF the traps were anchored at a fixed distance from the seafloor to allow deployment at a water depth of $10 \mathrm{~m}$. The traps were separated by $0.5 \mathrm{~m}$. Traps were deployed for $3 \mathrm{~d}$ intervals over a total of $9 \mathrm{~d}$. Chloroform $\left(\sim 0.56 \mathrm{ml} \mathrm{l}^{-1}\right)$ was added to the traps prior to deployment 
to preserve the sedimentation material. Collected material was filtered through pre-ashed glass fibre filters (25 mm GF/F, Whatman International), then analyzed in a FISON Instruments NA 1500 NC analyzer via flash combustion $\left(1020^{\circ} \mathrm{C}\right)$, and the gaseous products were measured by gas chromatography. POC and PON contents were calculated from an Atropina standard $\left(\mathrm{C}_{17} \mathrm{H}_{23} \mathrm{NO}_{3}\right)$.

\section{Sediment characteristics and pore water $\mathrm{NH}_{4}{ }^{+}$concentrations}

Surface sediment (0 to $2 \mathrm{~cm}$ depth) porosity was calculated from weight loss occurring after drying $5 \mathrm{ml}$ of wet sediment to a constant weight at $60^{\circ} \mathrm{C}$. The dried sediment was later used for analysis of POC and PON (see previous subsection).

To estimate organic matter mineralization rates in the sediments, $\mathrm{NH}_{4}{ }^{+}$production during anoxic sediment incubation was measured. Surface sediment $(0$ to $2 \mathrm{~cm}$ ) was homogenized and placed in $60 \mathrm{ml}$ centrifuge tubes that were then capped and kept in plastic bags filled with $\mathrm{N}_{2}$ gas during incubation. Bags were then buried in anoxic sediment in the dark at in situ temperature (closed jar incubations; Martens \& Berner 1974, Hulth et al. 1999). During incubation 3 samples were collected on 6 occasions comprising a time series. The jars were centrifuged for $20 \mathrm{~min}$ at 1060 relative centrifugal force, and pore water was collected and filtered through an acetate cellulose filter $(45 \mu \mathrm{m})$ and frozen immediately at $-20^{\circ} \mathrm{C}$ until analyzed for $\mathrm{NH}_{4}{ }^{+}$within 3 mo (see following subsection). Net mineralization rates were inferred from the initial linear increase in pore water $\mathrm{NH}_{4}{ }^{+}$concentrations. To account for reversible adsorption equilibrium with sediment particles, observed rates of ammonium release were multiplied by the factor $(1+K)$, where $K$ is the linear absorption coefficient estimated after shaking the sediment vigorously with $2 \mathrm{M} \mathrm{KCl}$ and comparing $\mathrm{NH}_{4}{ }^{+}$pore water concentrations of $\mathrm{KCl}$-extracted samples with that of natural sediment (Mackin \& Aller 1984).

Sediment profile imaging (SPI) was carried out on all sampling occasions at each station in order to estimate the depth of oxic and oxidized sediment. A camera was inserted into the sediment, and 5 replicate colour photographs $(16 \times 24 \mathrm{~cm})$ were taken of the top 12 to $15 \mathrm{~cm}$. The photographs were analyzed according to a benthic quality index (BQI) modified from the successional model of Pearson \& Rosenberg (1976) (Nilsson \& Rosenberg 1997). This index takes into account surface and subsurface structures such as faecal pellets, tubes, infauna and their burrows. Values vary between 0 and 15, reflecting sediment stress along an enrichment gradient. Well-oxidized sediment without hypoxia is represented by a BQI > 10, while BQI values from 5 to 10 indicate minor stress for a biodiverse community in which most of the functional groups are represented. BQI values from 2 to 4 suggest severe oxygen stress which may change benthic community structure to being dominated by opportunistic species, and finally BQI values of 0 to 2 indicate the absence of macrofauna. Additionally, the depth of the redox potential discontinuity (RPD) layer indicates the depth of oxidized sediment.

\section{Whole core flux incubations}

Upon their arrival in the laboratory, a gentle flow of seawater pumped from the deeper parts of the Gullmarfjord (40 m depth, in situ temperature, salinity = 34) was applied to each of the sediment cores, which were then stored at in situ temperature in the dark for $12 \mathrm{~h}$ before flux measurements were initiated so that added ${ }^{15} \mathrm{NO}_{3}{ }^{-}$could reach the nitrate reduction zone in the sediment (see below). To start the incubation process, cores were sealed with gas-tight lids containing 2 closable valves one for ingoing refill water and the other for outgoing sample collection. The overlying water was carefully mixed using a rotating (30 rpm) Tefloncoated stirring bar. Samples for analysis of dissolved nutrients $\left(\mathrm{NH}_{4}{ }^{+}, \mathrm{NO}_{2}{ }^{-}+\mathrm{NO}_{3}{ }^{-}, \mathrm{HPO}_{4}{ }^{2-}\right), \mathrm{DON}$ and $\mathrm{O}_{2}$ were collected in a time series of 6 samplings $(t=0$ to 5$)$. The length of each series depended on the time for reaching an $\mathrm{O}_{2}$ concentration $20 \%$ lower than the initial concentration, which varied from 0 to $14 \mathrm{~h}$ in Sep05 to 0 to $3 \mathrm{~h}$ in Sep06. After being filtered (0.45 $\mu \mathrm{m}$ cellulose acetate) and stored at $-20^{\circ} \mathrm{C}$, nutrient samples were analyzed with an automatic analyzer (TRAACS 800, Bran and Luebbe) using standard colorimetric methods (Strickland \& Parsons 1972). DON samples were oxidized to $\mathrm{NO}_{3}^{-}$before analysis on the TRAACS. Briefly, potassium persulfate was added to each $8 \mathrm{ml}$ sample in order to oxidize organic and inorganic $\mathrm{N}$ (total $\mathrm{N}$ [TN]) to nitrate. Oxidation was performed in a CertoClave (i.e. pressure cooker: Hochdruck-Sterilisator) for $30 \mathrm{~min}$ at $120^{\circ} \mathrm{C}$. Samples for oxidation yield background correction ( $\mathrm{n}=3$ ) and internal standards ( $\mathrm{n}=3$, glycine) were also included. DON was calculated as total nitrogen $\left(\mathrm{NH}_{4}{ }^{+}+\mathrm{NO}_{2}{ }^{-}+\mathrm{NO}_{3}{ }^{-}\right)$. 
Oxygen samples were precipitated using Winkler reagents, stored in the dark at $4^{\circ} \mathrm{C}$ and titrated within $12 \mathrm{~h}$. Incubation times were adjusted to achieve $<20 \%$ decrease in $\mathrm{O}_{2}$ concentration. Fluxes were calculated from changes in concentration over time in each core, with corrections made for refilled water replacing volume withdrawn.

\section{Denitrification}

Benthic denitrification rates were estimated from ${ }^{29} \mathrm{~N}_{2}$ and ${ }^{30} \mathrm{~N}_{2}$ production rates in the sediment flux cores, after the addition of ${ }^{15} \mathrm{~N}_{-} \mathrm{NO}_{3}{ }^{-}$to the overlying water in accordance with the isotope pairing technique (IPT; Nielsen 1992). After the flux incubation (see previous subsection), the same sediment cores were pre-incubated for $12 \mathrm{~h}$ with a continuous flow of ${ }^{15} \mathrm{~N}_{-} \mathrm{NO}_{3}{ }^{-}\left(50 \mu \mathrm{M}{ }^{15} \mathrm{~N}-\mathrm{NO}_{3}{ }^{-}\right)$in order to reach a steady state between ${ }^{14} \mathrm{~N}-\mathrm{NO}_{3}{ }^{-}$and ${ }^{15} \mathrm{~N}-\mathrm{NO}_{3}{ }^{-}$in the nitrate reduction zone. Nitrate concentrations in the overlying water were measured before and after the addition of ${ }^{15} \mathrm{NO}_{3}{ }^{-}$in order to estimate the ${ }^{14} \mathrm{NO}_{3}{ }^{-}$/ ${ }^{15} \mathrm{NO}_{3}{ }^{-}$ratio. At the start of the incubation, 6 cores from each station were sealed with gas-tight lids. The cores were then sampled at fixed times until $<20 \%$ decrease in $\mathrm{O}_{2}$ concentration was observed (see above). During sampling the water column and sediment were carefully mixed with an aliquot of the resultant slurry transferred to $12 \mathrm{ml}$ gas-tight glass vials (Exetainer, Labco) for determination of ${ }^{29} \mathrm{~N}_{2}$ and ${ }^{30} \mathrm{~N}_{2}$ concentrations. Zinc chloride $(0.1 \mathrm{ml}$ of $7 \mathrm{M} \mathrm{ZnCl}_{2}$ ) was added to the sampling tube (Exetainer) for preservation. Concentrations of ${ }^{29 / 30} \mathrm{~N}_{2}$ were determined using an isotope ratio gas chromatography-mass spectrometer (RoboPrep G+ online with a Tracer Mass, Europa Scientific) and calculated as excess above their natural abundances. The IPT provides measures of denitrification involving nitrate diffusing from the overlying water column (Dw), and coupled nitrification/denitrification in which nitrate originates from nitrification within the sediment (Dn).

IPT has been shown to be biased in sediments associated with significant anammox contributions (>10\% anammox to total $\mathrm{N}_{2}$ production; Risgaard-Petersen et al. 2004, Trimmer et al. 2005). In the present study, potential anammox in surface sediment $(0$ to $2 \mathrm{~cm})$ was measured in homogenized anoxic sediment incubations in May 2005 following the method of Thamdrup \& Dalsgaard (2002). According to these results, anammox contributed 7 to $9 \%$ of total $\mathrm{N}_{2}$ production at all stations and was considered insignificant.

\section{Sulfate reduction rates}

Sediment cores $(2.6 \mathrm{~cm})$ were pre-incubated overnight at in situ temperature. ${ }^{35} \mathrm{~S}-\mathrm{SO}_{4}{ }^{2-}$-tracer $(2 \mu \mathrm{l})$ from an $80 \mathrm{kBq}^{-1}$ solution was then injected through the silicone-filled ports at $1 \mathrm{~cm}$ intervals from the surface down to a depth of $10 \mathrm{~cm}$, and the cores were incubated for 6 to $11 \mathrm{~h}$. Samples were sliced at $1 \mathrm{~cm}$ intervals down to a depth of $6 \mathrm{~cm}$ and at $2 \mathrm{~cm}$ intervals down to $10 \mathrm{~cm}$ depth, before being fixed with zinc acetate $\left[20 \% \mathrm{Zn}\left(\mathrm{O}_{2} \mathrm{CCH}_{3}\right)_{2}\right]$ and stored frozen at $-25^{\circ} \mathrm{C}$. SRR was determined using the 1 step distillation procedure (Fossing \& Jørgensen 1987). Approximately $2 \mathrm{~g}$ homogenized sediment from each slice was transferred to a reaction flask containing $5 \mathrm{ml}$ water and $10 \mathrm{ml} \mathrm{50 \%} \mathrm{ethanol.} \mathrm{After}$ degassing with $\mathrm{N}_{2}$ for 10 min, the slurry was acidified via the addition of $8 \mathrm{ml}$ of $12 \mathrm{M} \mathrm{HCl}$ and $16 \mathrm{ml}$ of $1 \mathrm{M}$ $\mathrm{Cr}^{2+}$ added to $0.5 \mathrm{M} \mathrm{HCl}$, before being distilled by boiling for $45 \mathrm{~min}$. TRS was trapped as $\mathrm{ZnS}$ in $10 \mathrm{ml}$ of $5 \% \mathrm{Zn}\left(\mathrm{O}_{2} \mathrm{CCH}_{3}\right)_{2}$, with subsamples then mixed with scintillation liquid and counted on a liquid scintillation analyzer.

\section{Data analysis}

Bottom water oxygen and nutrient concentrations, sediment characteristics, sedimentation rates, fluxes and sulfate reduction rates were compared between (1) stations, (2) farms nested within station and (3) sampling times using a 3 factorial general linear model analysis of variance. Data from May05 (before the mussel farms were established) were not included in any statistical tests due to lack of a reference station. Tukey post hoc tests were performed in cases of significance $(\alpha<0.05)$. Homogeneity of variance and normality were assumed according to Levene's and Kolmogrov-Smirnov's tests. The relationships between (1) $\mathrm{N}$ sedimentation and $\mathrm{NH}_{4}{ }^{+}$flux and (2) $\mathrm{C}$ sedimentation and TOU were tested by linear regression $(\alpha<0.05)$.

The $\mathrm{N}$ budget was calculated from $\mathrm{N}$ sedimentation, denitrification and $\mathrm{N}$ fluxes (input vs. removal through denitrification) at M2 and M3. Sedimentation rates of PON were used as a proxy for the total $(100 \%)$ input of $\mathrm{N}$ to sediment from the water column (REF) and mussel farms (FS). Rates are presented in mmol m-2 $\mathrm{d}^{-1}$. The amount of $\mathrm{N}$ recycled into the water column was estimated in percent of the PON sedimentation from the benthic fluxes of $\mathrm{DON}, \mathrm{NH}^{+}$ and $\mathrm{NO}_{3}{ }^{-}$, with denitrification rates representing the removal of $\mathrm{N}$ from the system. 


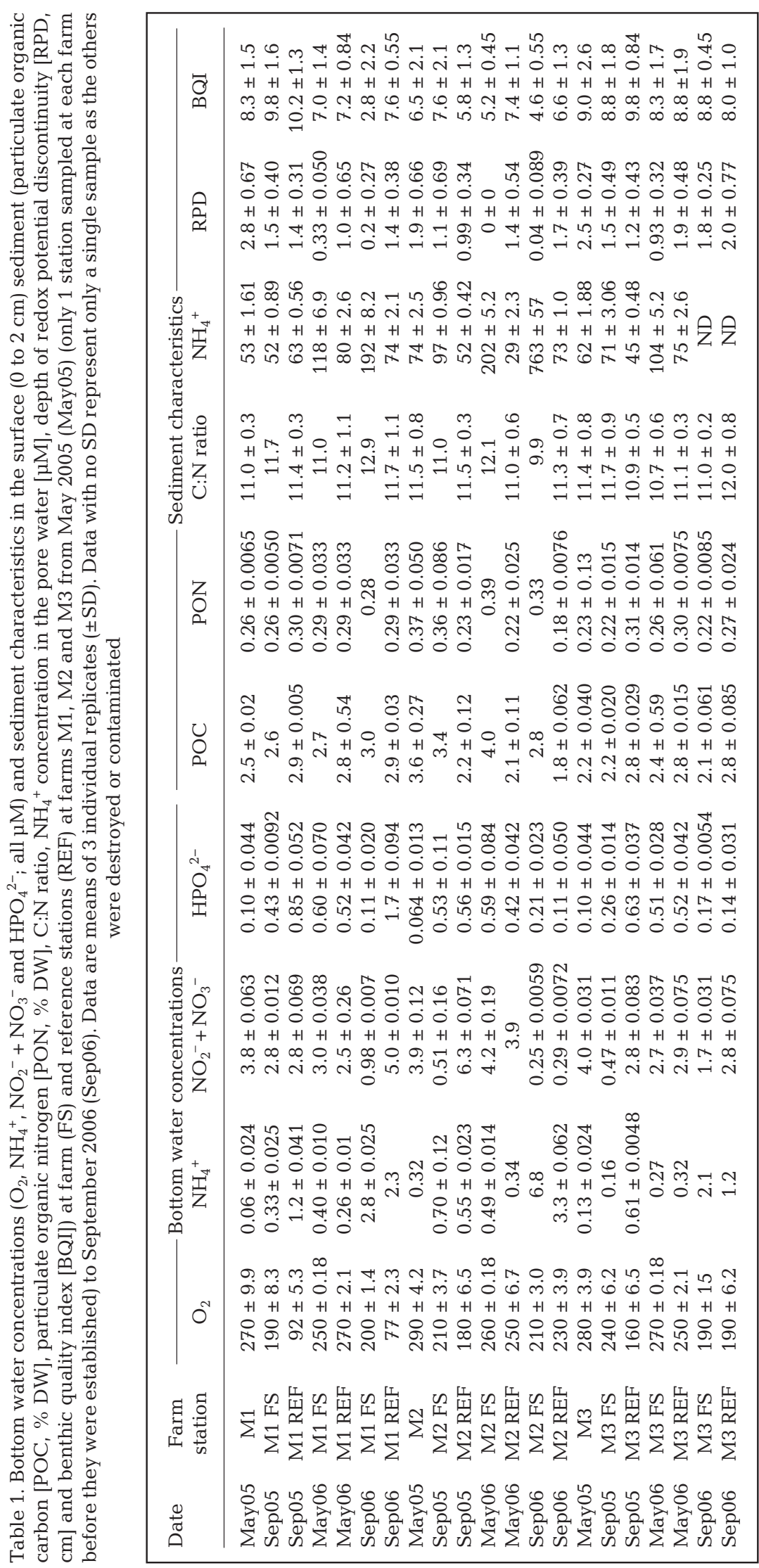

\section{RESULTS}

\section{Bottom water and sediment characteristics}

Physical properties, and oxygen and nutrient concentrations

Bottom water temperature ranged from $7^{\circ} \mathrm{C}$ in May to $16-17^{\circ} \mathrm{C}$ in September, while salinity remained constant at 31. Oxygen concentrations ranged between 160 and $290 \mu \mathrm{M}$, corresponding to saturation levels of 53 to $95 \%$, at all sites throughout the entire study period, with the exception of the M1 reference station in Sep05 and Sep06 which exhibited lower $\mathrm{O}_{2}$ concentrations of 92 and $77 \mu \mathrm{M}$, respectively (Table 1 ). The bottom $\mathrm{O}_{2}$ concentration was significantly different between stations (FS and REF) $(p=0.0007)$, between farms (M1, M2 and M3) within stations $(\mathrm{p}=0.0016)$ and between times (Table 2). Nutrient concentrations in bottom water were generally low, with levels below $1 \mu \mathrm{M}$ for $\mathrm{NH}_{4}{ }^{+}$and $\mathrm{HPO}_{4}{ }^{2-}$. The only exception was $\mathrm{NH}_{4}{ }^{+}$in Sep06 at M1 and M2, which varied between 2.3 and $6.8 \mu \mathrm{M}$, with the highest concentrations observed at the farm sites. Bottom water $\mathrm{NO}_{3}{ }^{-}$ and $\mathrm{NH}_{4}{ }^{+}$concentrations ranged between 0.3 and $6.3 \mu \mathrm{M}$ and 0.06 and $6.8 \mu \mathrm{M}$, respectively, over the study period (Table 1). In some cases, values were higher at FS than at REF (e.g. for $\mathrm{NH}_{4}{ }^{+}$), while, in other cases, they were lower at FS than at REF (e.g. for $\mathrm{HPO}_{4}{ }^{-}$at M1) (Table 2). All stations were characterized by muddy sediment with a porosity of 0.79 to 0.82 (data not shown). Sediment at M1 contained a larger fraction of shell gravel compared to M2 and M3. Surface sediment $(0$ to $2 \mathrm{~cm}$ ) had a POC content of 2 to $3 \%$ DW and a C:N ratio of between 13 and 15 at all stations (Table 1). The POC and PON contents were only significantly higher at FS than at REF at one of the farms (M2). Pore 
Table 2. General linear model analysis of variance of $\mathrm{O}_{2}, \mathrm{NH}_{4}{ }^{+}, \mathrm{NO}_{3}{ }^{-}+\mathrm{NO}_{2}{ }^{-}$and $\mathrm{HPO}_{4}{ }^{2-}$ concentrations in bottom water, $\mathrm{POC}$ and PON content in surface sediment, $\mathrm{NH}_{4}{ }^{+}$concentration in pore water, and RPD and BQI in the sediment with factors station (FS and REF), farms within station [M1(FS and REF), M2(FS and REF), M3(FS and REF)] and time (Sep05, May06 and Sep06). Abbreviations as in Table 1

\begin{tabular}{|c|c|c|c|c|c|}
\hline \multirow[t]{2}{*}{ Variable } & \multirow[t]{2}{*}{ Source of variability } & \multirow[t]{2}{*}{$\mathrm{df}$} & \multirow[t]{2}{*}{$\mathrm{p}$} & & \multirow{2}{*}{ Tukey test } \\
\hline & & & & Station & \\
\hline \multicolumn{6}{|l|}{ Bottom water } \\
\hline \multirow{5}{*}{$\mathrm{O}_{2}$} & Station & 1 & 0.0007 & M1: FS > REF & M1: May06 > Sep05 = Sep06 \\
\hline & Farm (Station) & 4 & 0.0016 & $\mathrm{M} 2: \mathrm{FS}=\mathrm{REF}$ & M2: May06 > Sep05 = Sep06 \\
\hline & Time & 2 & $<0.0001$ & M3: FS > REF & M3: May06 > Sep05 = Sep06 \\
\hline & Station $\times$ Time & 2 & 0.0159 & & \\
\hline & Error & 26 & & & \\
\hline \multirow[t]{5}{*}{$\mathrm{NH}_{4}^{+}$} & Station & 1 & 0.043 & M1: FS = REF & M1: Sep06 > Sep05 = May06 \\
\hline & Farm (Station) & 4 & 0.0079 & M2: FS > REF & M2: Sep06 > Sep05 = May06 \\
\hline & Time & 2 & $<0.0001$ & M3: FS = REF & M3: Sep06 > Sep05 = May06 \\
\hline & Treatment $\times$ Time & 2 & 0.016 & & \\
\hline & Error & 25 & & & \\
\hline \multirow[t]{5}{*}{$\mathrm{NO}_{3}^{-}+\mathrm{NO}_{2}^{-}$} & Treatment & 1 & 0.0056 & M1: REF > FS & \\
\hline & Farm (Treatment) & 4 & 0.79 & M2: REF > FS & \\
\hline & Time & 2 & 0.072 & M3: REF > FS & \\
\hline & Treatment $\times$ Time & 2 & 0.056 & & \\
\hline & Error & 26 & & & \\
\hline \multirow[t]{5}{*}{$\mathrm{HPO}_{4}{ }^{2-}$} & Treatment & 1 & 0.0019 & M1: REF > FS & \\
\hline & Farm (Treatment) & 4 & 0.0073 & M2: FS > REF & \\
\hline & Time & 2 & 0.15 & M3: REF > FS & \\
\hline & Treatment $\times$ Time & 2 & 0.022 & & \\
\hline & Error & 26 & & & \\
\hline \multicolumn{6}{|l|}{ Sediment } \\
\hline \multirow[t]{5}{*}{ POC } & Treatment & 1 & 0.38 & M1: FS = REF & \\
\hline & Farm (Treatment) & 4 & $<0.0001$ & M2: FS > REF & \\
\hline & Time & 2 & 0.098 & M3: $F S=R E F$ & \\
\hline & Treatment $\times$ Time & 2 & 0.21 & & \\
\hline & Error & 35 & & & \\
\hline \multirow[t]{5}{*}{ PON } & Treatment & 1 & 0.33 & M1: FS = REF & M1: Sep05 = May06 = Sep06 \\
\hline & Farm (Treatment) & 4 & $<0.0001$ & M2: FS > REF & M2: May06 > Sep06 \\
\hline & Time & 2 & 0.020 & M3: FS = REF & M3: Sep05 = May06 = Sep06 \\
\hline & Treatment $\times$ Time & 2 & 0.19 & & \\
\hline & Error & 35 & & & \\
\hline \multirow{5}{*}{$\mathrm{NH}_{4}^{+}$} & Treatment & 1 & 0.0002 & M1: FS > REF & M1: Sep06 > Sep05 \\
\hline & Farm (Treatment) & 4 & 0.0005 & M2: FS > REF & M2: Sep06 > Sep05 \\
\hline & Time & 2 & $<0.0001$ & M3: FS > REF & \\
\hline & Treatment $\times$ Time & 2 & $<0.0001$ & & \\
\hline & Error & 30 & & & \\
\hline \multirow[t]{5}{*}{ RPD } & Treatment & 1 & $<0.0001$ & M1: REF > FS & \\
\hline & Farm (Treatment) & 4 & $<0.0001$ & M2: REF > FS & \\
\hline & Time & 2 & 0.073 & M3: FS = REF & \\
\hline & Treatment $\times$ Time & 2 & $<0.0001$ & & \\
\hline & Error & 77 & & & \\
\hline \multirow[t]{5}{*}{ BQI } & Treatment & 1 & & M1: REF > FS & M1: Sep05 > Sep06 \\
\hline & Farm (Treatment) & 4 & $<0.0001$ & M2: REF > FS & M2: Sep05 = May06 = Sep06 \\
\hline & Time & 2 & $<0.0001$ & M3: FS = REF & M3: Sep05 = May06 $=$ Sep06 \\
\hline & Treatment $\times$ Time & 2 & 0.052 & & \\
\hline & Error & 77 & & & \\
\hline
\end{tabular}

water $\mathrm{NH}_{4}{ }^{+}$concentrations in surface sediment (0 to $2 \mathrm{~cm}$ ) varied significantly between FS and REF ( $\mathrm{p}=0002)$, between farms (within stations) $(\mathrm{p}=$ $0.0005)$ and between times $(p=0.001)$, with maximum $\mathrm{NH}_{4}{ }^{+}$concentrations occurring at FS in Sep06
(Tables 1 \& 2). Concentrations at FS were 55 to $85 \%$ higher in Sep05 and 150 to 950\% higher in Sep06 compared to REF. Concentrations at REF ranged between 45 and $75 \mu \mathrm{M}$ throughout the study period. Except for POC and PON in the sediment, station and 
sampling time interacted significantly for the bottom water nutrients, pore water $\mathrm{NH}_{4}{ }^{+}$and sediment characteristics (Table 2).

\section{Sediment profile imaging}

BQI values calculated from sediment profile imaging indicated only minor stress levels at M3 with a biodiverse community (FS $8.3 \pm 1.7$ and REF $9.8 \pm 0.83$ ) observed at all samplings (Table 1$)$. At M1 and M2, BQI at FS had decreased by 170 and $45 \%$, respectively, compared to REF where it remained at the same level throughout the whole sampling period (Table 1). The RPD depth varied between 1 and $3 \mathrm{~cm}$ at REF stations (Table 1), while the RPD at FS at M2 decreased and was undetectable in both May06 and Sep06. The RPD depth was also affected by the mussel farm at M1 being a percentage of 200 and 600 higher at FS compared to REF in May06 and Sep06, respectively. Both RPD and BQI varied significantly between stations, farms within each station and time except at M3 where no effects were observed (Table 2).

\section{Sedimentation rates}

Sedimentation rates were measured at M2 and M3 and showed significantly higher POC and PON sedimentation at FS compared to REF (Tables 3 \& 4), with rates at FS 3 to 4 times higher at both farms. Furthermore, sedimentation rates were significantly higher at M2 compared at M3 within each station. Mean $\mathrm{C}: \mathrm{N}$ ratios of trapped material at both farms were not significantly different between FS and REF ( $p>0.05$; Table 3). Due to higher $\mathrm{N}$ content, $\mathrm{C}: \mathrm{N}$ ratios was lower in suspended material (Table 3) with respect to that of the surface sediment (Table 1).

Table 3. Sedimentation rates $\left(\mathrm{g} \mathrm{m}^{-2} \mathrm{~d}^{-1}\right)$ of dry matter (DM), particulate organic carbon (POC), particulate organic nitrogen $(\mathrm{PON})$ and $\mathrm{C}: \mathrm{N}$ ratio $( \pm \mathrm{SD})$ at the mussel farms $\mathrm{M} 2$ and M3 in Lysekil in September 2006. Data are means of 3 deployments $( \pm \mathrm{SD}) .{ }^{*}$ : significant effect of the mussel farms (FS: farm station) $(p<0.05)$ compared with the reference (REF) station

\begin{tabular}{|lllll|}
\hline & \multicolumn{4}{c|}{ Sedimentation rate } \\
\cline { 2 - 5 } & DM & POC & PON & C:N ratio \\
\hline M2 FS & $36 \pm 4.7^{*}$ & $2.50 \pm 1.21^{*}$ & $0.27 \pm 0.13^{*}$ & $9.3 \pm 0.4$ \\
M2 REF & $23 \pm 2.2$ & $0.57 \pm 0.22$ & $0.06 \pm 0.02$ & $8.6 \pm 2.0$ \\
M3 FS & $28 \pm 3.5$ & $1.60 \pm 1.13^{*}$ & $0.17 \pm 0.04$ & $9.7 \pm 1.7$ \\
M3 REF & $19 \pm 1.4$ & $0.40 \pm 0.17$ & $0.05 \pm 0.02$ & $8.0 \pm 1.1$ \\
\hline
\end{tabular}

\author{
Sediment metabolism \\ TOU, $\mathrm{NH}_{4}{ }^{+}$and DON flux
}

After 12 to 16 mo of operation, benthic fluxes were significantly higher at FS compared to REF at all farms (Fig. 2A, Table 4). Farms within stations varied significantly, with the highest flux levels at M2 FS. Fluxes varied with sampling time as they generally increased from Sep05 to May06 and Sep06 (Fig. 2, Table 4), e.g. $\mathrm{NH}_{4}{ }^{+}$fluxes at REF stations were generally $<0.5 \mathrm{mmol} \mathrm{m}^{-2} \mathrm{~d}^{-1}$, whereas the $\mathrm{NH}_{4}{ }^{+}$efflux in Sep06 was 13 times higher at M2 FS (Fig. 2A). Simultaneously, the highest bottom water and pore water $\mathrm{NH}_{4}{ }^{+}$concentration $(6.8 \mu \mathrm{M})$ was also observed at M2 (Table 1). DON fluxes were in the same range as those of $\mathrm{NH}_{4}{ }^{+}$(Fig. 2B), with the highest values measured at M2 in May06 and Sep06. TOU was moderate at the REF stations (10 to $15 \mathrm{mmol} \mathrm{m}^{-2} \mathrm{~d}^{-1}$ ) throughout the sampling period (Fig. 2C), but after the first year of active farming TOU had increased by 100 to $400 \%$ at the farm stations with respect to the REF stations. The greatest discrepancy between REF and FS was observed at M2 in Sep06 (Fig. 2C). However, no differences were observed in Sep05, i.e. 2 mo after the establishment of the mussel farms. Both $\mathrm{NH}_{4}{ }^{+}$ flux and TOU increased significantly with increased sedimentation (Fig. 3A, $\mathrm{B}_{i} \mathrm{p}=0.043$ and $\mathrm{p}=0.021$, respectively). Fluxes of $\mathrm{NO}_{2}^{-}+\mathrm{NO}_{3}^{-}$were low and inconsistent with both uptake and release of $\mathrm{NO}_{\mathrm{x}}$ throughout the study, except for Sep2006 when all farm stations showed an uptake of $\mathrm{NO}_{2}{ }^{-}+\mathrm{NO}_{3}{ }^{-}$from the water column, while sediment at the REF was a source of $\mathrm{NO}_{3}{ }^{-}$(Table 5). The $\mathrm{HPO}_{4}{ }^{2-}$ flux was generally low $\left(<0.1 \mathrm{mmol} \mathrm{m}^{-2} \mathrm{~d}^{-1}\right)$, although it did increase to $1.14 \mathrm{mmol} \mathrm{m}^{-2} \mathrm{~d}^{-1}$ in May06 at M2 FS and to 0.30 $\mathrm{mmol} \mathrm{m} \mathrm{m}^{-2} \mathrm{~d}^{-1}$ at M2 FS in Sep06 (Table 5).

\section{Denitrification}

Coupled nitrification-denitrification, Dn, dominated denitrification rates at all stations in all seasons, making an average contribution to total denitrification of $82 \% \pm 8.1$ (Fig. 4). Total denitrification rates were $<2 \mathrm{mmol} \mathrm{m} \mathrm{m}^{-2}$ at $\mathrm{M} 1$ and $\mathrm{M} 2$, and approximately twice as high at M3 (Fig. 4). While at M1 there was no significant difference between denitrification rates below the farm and REF stations, Dn was significantly lower at FS than REF at M2. Furthermore, denitrification rates decreased with time (from Sep05 until Sep06) at both FS and REF at M2. A similar decrease in denitrification rate over time 
Table 4. General linear model analysis of variance of sedimentation rate, $\mathrm{O}_{2}$, dissolved organic nitrogen $(\mathrm{DON}), \mathrm{NH}_{4}{ }^{+}$, $\mathrm{NO}_{3}{ }^{-}+\mathrm{NO}_{2}{ }^{-}$and $\mathrm{HPO}_{4}{ }^{2-}$ flux and sulfate reduction rate with factors station (FS and REF), farms within station [M1(FS and REF), M2(FS and REF), M3(FS and REF)] and time (Sep05, May06 and Sep06). nd = no data from this farm. Other abbreviations as in Table 1

\begin{tabular}{|c|c|c|c|c|c|}
\hline \multirow{2}{*}{ Variable } & \multirow[t]{2}{*}{ Source of variability } & \multirow[t]{2}{*}{$\mathrm{df}$} & \multirow[t]{2}{*}{$\mathrm{p}$} & \multicolumn{2}{|r|}{ - Tukey test } \\
\hline & & & & Station & Time \\
\hline \multirow[t]{3}{*}{ Sedimentation } & Treatment & 1 & 0.0051 & M1: nd & nd \\
\hline & Farm(treatment) & 2 & 0.1239 & M2: FS > REF & \\
\hline & Error & 8 & & M3: FS > REF & \\
\hline \multicolumn{6}{|l|}{ Benthic flux } \\
\hline \multirow[t]{5}{*}{$\mathrm{O}_{2}$} & Treatment & 1 & $<0.0001$ & M1: FS > REF & M1: Sep05 < May06 = Sep06 \\
\hline & Farm(treatment) & 4 & 0.033 & M2: FS > REF & M2: Sep05 < May06 = Sep06 \\
\hline & Time & 2 & $<0.0001$ & M3: FS > REF & M3: Sep05 $<$ May06 = Sep06 \\
\hline & Treatment $\times$ Time & 2 & $<0.0001$ & & \\
\hline & Error & 98 & & & \\
\hline \multirow[t]{5}{*}{ DON } & Treatment & 1 & 0.0001 & M1: FS = REF & M1: Sep05 < May06 \\
\hline & Farm(treatment) & 4 & $<0.0001$ & M2: FS $<$ REF & M2: Sep05 = May06 = Sep06 \\
\hline & Time & 2 & 0.015 & M3: FS = REF & M3: Sep05 $=$ May06 $=$ Sep06 \\
\hline & Treatment $\times$ Time & 2 & 0.0005 & & \\
\hline & Error & 98 & & & \\
\hline \multirow[t]{5}{*}{$\mathrm{NH}_{4}^{+}$} & Treatment & 1 & 0.0045 & M1: FS > REF & M1: Sep05 = May05 < Sep06 \\
\hline & Farm(treatment) & 4 & 0.0014 & M2: FS > REF & M2: Sep05 = May05 $<$ Sep06 \\
\hline & Time & 2 & $<0.0001$ & M3: FS > REF & M3: Sep05 = May05 $<$ Sep06 \\
\hline & Treatment $\times$ Time & 2 & 0.0012 & & \\
\hline & Error & 98 & & & \\
\hline \multirow[t]{5}{*}{$\mathrm{NO}_{3}^{-}+\mathrm{NO}_{2}^{-}$} & Treatment & 1 & 0.033 & M1: FS $<$ REF & M1: Sep05 = Sep06 < May06 \\
\hline & Farm(treatment) & 4 & 0.0073 & M2: FS $<$ REF & M2: Sep05 $=$ Sep06 $<$ May06 \\
\hline & Time & 2 & $<0.0001$ & M3: FS = REF & M3: Sep05 = May06 $=$ Sep06 \\
\hline & Treatment $\times$ Time & 2 & 0.0043 & & \\
\hline & Error & 97 & & & \\
\hline \multirow[t]{5}{*}{$\mathrm{HPO}_{4}^{-}$} & Treatment & 1 & 0.005 & M1: REF > FS & M1: Sep05 < May06 \\
\hline & Farm(treatment) & 4 & $<0.0001$ & M2: FS > REF & M2: Sep05 < May06 \\
\hline & Time & 2 & 0.016 & M3: FS > REF & M3: May06 < Sep06 \\
\hline & Treatment $\times$ Time & 2 & 0.022 & & \\
\hline & Error & 98 & & & \\
\hline \multirow[t]{3}{*}{ Sulfate reduction } & Treatment & 1 & 0.0003 & M1: FS = REF & \\
\hline & Farm(treatment) & 4 & 0.062 & M2: FS > REF & \\
\hline & Error & 9 & & M3: FS > REF & \\
\hline
\end{tabular}

was observed at M3 during the same period, although here denitrification was in fact stimulated below the farm (Fig. 4).

SRR

Depth-integrated SRR was significantly affected by the farm stations by a factor of 2.5 to 15 or 1 to $3 \mathrm{mmol} \mathrm{m} \mathrm{m}^{-2} \mathrm{~d}^{-1}$ from May05 to May06 (Tables 4 \& 5). The largest difference between REF and FS was observed at M2 (1.6 \pm 0.46 and $17.0 \pm 4.5 \mathrm{mmol}$ $\mathrm{m}^{-2} \mathrm{~d}^{-1}$, respectively). Analysis of depth profiles revealed that maximum SRR values tended to occur between 2 and $6 \mathrm{~cm}$ depth, although in May06 at M2 FS maximum values were found in the uppermost layer (Fig. 5). $\mathrm{NH}_{4}{ }^{+}$fluxes correlated signifi- cantly with $\operatorname{SRR}\left(\mathrm{R}^{2}=0.89, \mathrm{p}=0.0003\right.$, respectively) but not with TOU ( $p=0.16)$.

\section{$\mathrm{N}$ budget}

Total PON sedimentation was $19 \pm 9.3 \mathrm{mmol} \mathrm{m}^{-2}$ $\mathrm{d}^{-1}(\mathrm{FS})$ and $4.6 \pm 1.6 \mathrm{mmol} \mathrm{m}^{-2} \mathrm{~d}^{-1}(\mathrm{REF})$ at $\mathrm{M} 2$ and $12 \pm 2.8 \mathrm{mmol} \mathrm{m}^{-2} \mathrm{~d}^{-1}(\mathrm{FS})$ and $3.4 \pm 1.5 \mathrm{mmol} \mathrm{m}^{-2} \mathrm{~d}^{-1}$ (REF) at M3. The amount of $\mathrm{N}$ recycled into the water column was estimated, in percentages of the PON sedimentation, from the benthic flux of DON, $\mathrm{NH}_{4}{ }^{+}$ and $\mathrm{NO}_{3}{ }^{-}$, with denitrification rates revealing how much was removed from the system. $\mathrm{N}$ was predominantly returned to the water column as DON or $\mathrm{NH}_{4}{ }^{+}$ at M2 (27 and 20\%, respectively, at FS) and as $\mathrm{NH}_{4}{ }^{+}$ at M3 (10\% at FS). Only $1 \%$ was removed through 

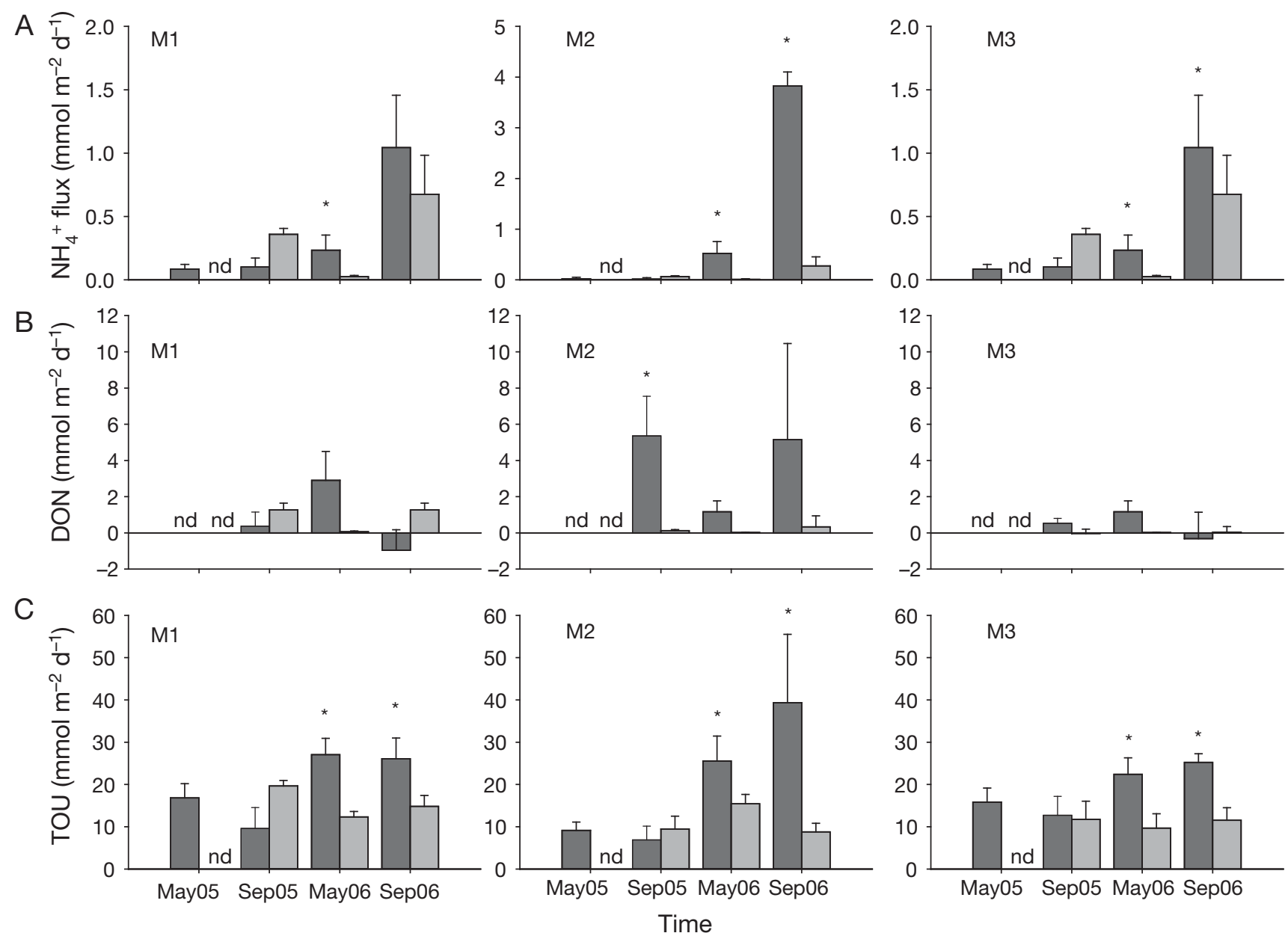

Fig. 2. Average $(\mathrm{n}=6 ;+\mathrm{SD})$ fluxes of $(\mathrm{A})$ ammonium $\left(\mathrm{NH}_{4}{ }^{+}\right)$, (B) dissolved organic nitrogen (DON) and (C) total oxygen uptake (TOU). Dark and light grey bars represent farm stations (FS) and reference stations (REF), respectively. Measurements were carried out at 3 mussel farms (M1, M2 and M3) in Lysekil 4 times from May 2005 to September 2006. Samplings in May05 were conducted before the mussel farms were established. nd: no data available; ${ }^{*}$ : a significant effect of the mussel farm ( $p<0.05$ )
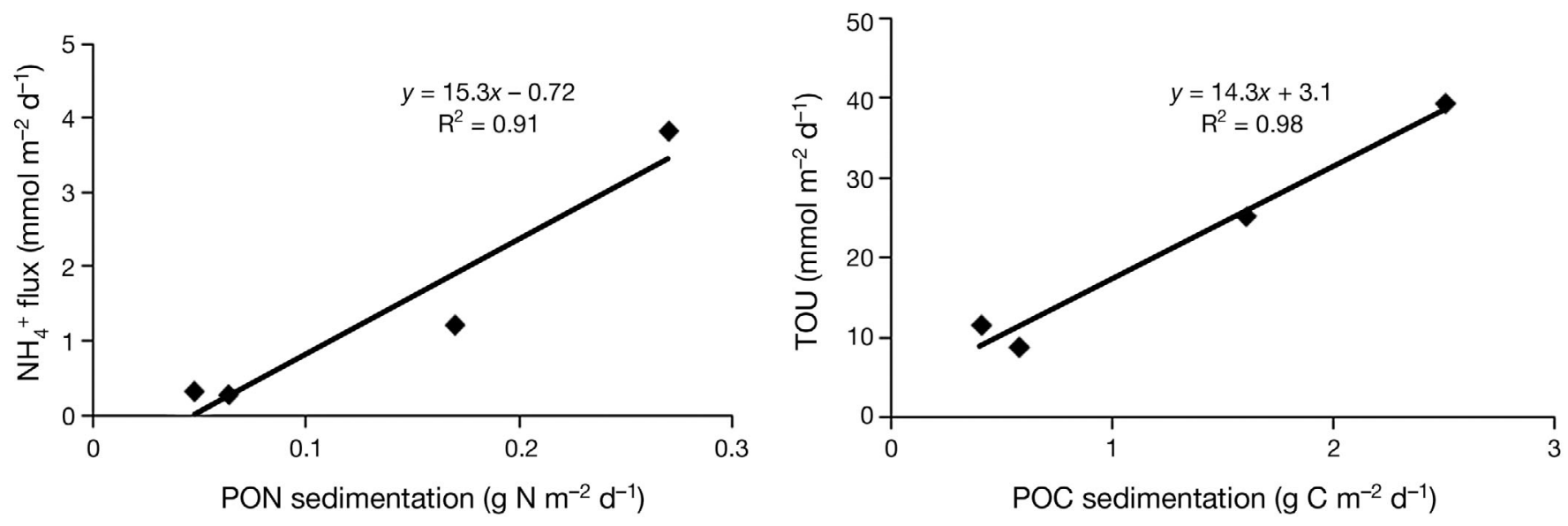

Fig. 3. Sedimentation rates of (A) particulate organic nitrogen (PON) versus $\mathrm{NH}_{4}{ }^{+}$flux and (B) POC versus TOU, measured in September 2006 at M2 and M3. Other abbreviations as in Fig. 2 
Table 5. Depth-integrated sulfate reduction rate (SRR, mmol m$\left.{ }^{-2} \mathrm{~d}^{-1}\right)$ and $\mathrm{NO}_{2}{ }^{-}+\mathrm{NO}_{3}{ }^{-}$and $\mathrm{HPO}_{4}{ }^{2-}$ fluxes $\left(\mu \mathrm{mol} \mathrm{m}{ }^{-2} \mathrm{~d}^{-1}\right) \mathrm{mea}^{-}$ sured from May 2005 (before the mussel farms were established) to September 2006. Data represent a mean of 5 replicates $( \pm \mathrm{SD}) .{ }^{*}$ : a significant effect of the mussel farms $(\mathrm{p}<0.05)$. Other abbreviations as in Table 1

\begin{tabular}{|c|c|c|c|c|c|c|c|}
\hline \multirow{2}{*}{ Parameter } & \multirow{2}{*}{ Time } & \multicolumn{2}{|c|}{ M1 } & \multicolumn{2}{|c|}{ M2 } & \multirow[b]{2}{*}{ FS } & \multirow[b]{2}{*}{ REF } \\
\hline & & FS & REF & FS & REF & & \\
\hline \multirow[t]{2}{*}{ SRR } & May05 & 3.1 & & 1.1 & & $2.7 \pm 1.1$ & \\
\hline & May06 & $6.9 \pm 5.8$ & $1.8 \pm 0.8$ & $17.0 \pm 4.5^{*}$ & $1.6 \pm 0.5$ & $10.0 \pm 0.1^{*}$ & $1.1 \pm 0.5$ \\
\hline \multirow{4}{*}{$\mathrm{NO}_{3}^{-}+\mathrm{NO}_{2}^{-}$} & May05 & $-146 \pm 416$ & & $-48 \pm 149$ & & $-214 \pm 137$ & \\
\hline & Sep05 & $1.15 \pm 86$ & $-178 \pm 168$ & $-228 \pm 72$ & $-24 \pm 223$ & $201 \pm 170$ & $-283 \pm 196$ \\
\hline & May06 & $104 \pm 174$ & $166 \pm 76$ & $320 \pm 829$ & $254 \pm 88$ & $104 \pm 174$ & $166 \pm 76$ \\
\hline & Sep06 & $-219 \pm 462$ & $42 \pm 133$ & $-874 \pm 679$ & $81 \pm 202$ & $-14 \pm 34$ & $42 \pm 37$ \\
\hline \multirow[t]{4}{*}{$\mathrm{HPO}_{4}{ }^{2-}$} & May05 & $-0.55 \pm 18$ & & $-12 \pm 2.5$ & & $-2.7 \pm 15$ & \\
\hline & Sep05 & $19 \pm 41$ & $106 \pm 50$ & $16 \pm 23$ & $82 \pm 30$ & $60 \pm 34$ & $23 \pm 27$ \\
\hline & May06 & $98 \pm 103$ & $80 \pm 113$ & $1138 \pm 762$ & $14 \pm 14$ & $15 \pm 26$ & $11 \pm 3.7$ \\
\hline & Sep06 & $76 \pm 85$ & $143 \pm 46$ & $303 \pm 323$ & $69 \pm 40$ & $82 \pm 30$ & $69 \pm 40$ \\
\hline
\end{tabular}

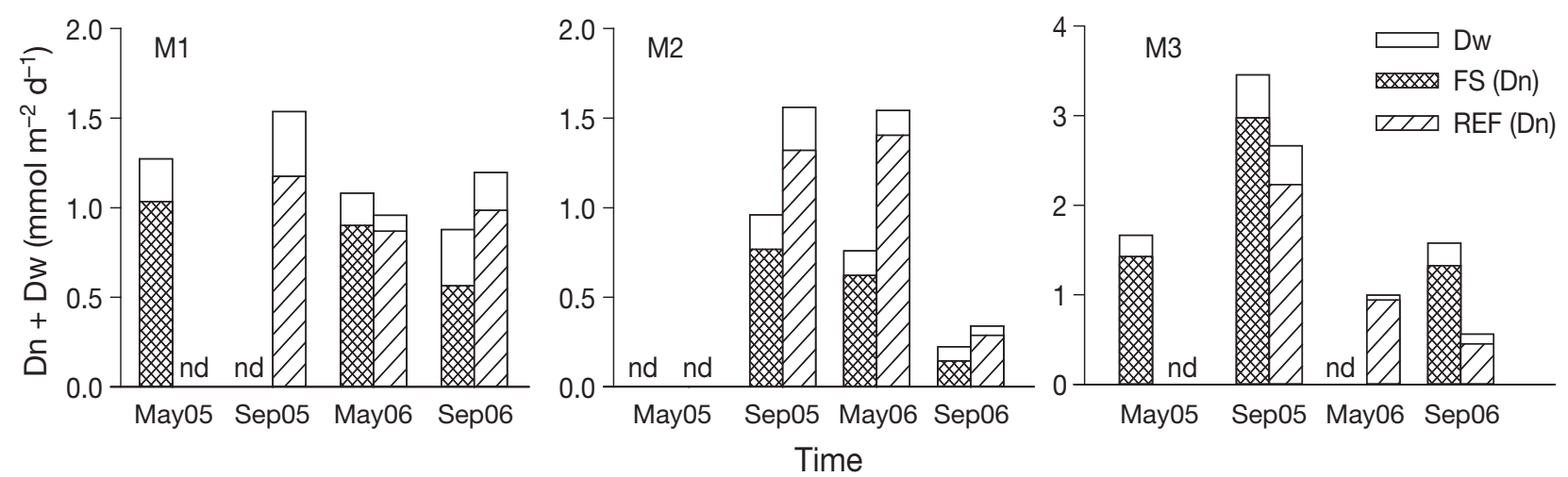

Fig. 4. Denitrification rates based on coupled nitrification-denitrification (Dn) and denitrification with nitrate from the overlying water (Dw) measured at M1, M2 and M3 from May 2005 to September 2006. Samplings in May 2005 were done before the mussel farms were established. Denitrification rates were calculated from a time series with 6 cores ( $\mathrm{n}=1$; see 'Sediment metabolism — Denitrification'). nd: no data available. Abbreviations as in Fig. 2

denitrification at the farm station at M2, compared to $10 \%$ at M3 (Fig. 6). The following section discusses these results with respect to the removal of $\mathrm{N}$ after 1 mussel harvest cycle (16 mo).

\section{DISCUSSION}

\section{Sedimentation and sediment composition}

The present study shows that the establishment of the Lysekil mussel farms increased the local sedimentation rates and affected underlying sediment by consistently increasing benthic oxygen demand and nutrient release. Measured sedimentation rates are in the same range as those reported in earlier studies of mussel farms with similar production size, in both Sweden (Dahlbäck \& Gunnarsson 1981) and Denmark (Carlsson et al. 2009). However, sedimentation rates at the M2 farm were almost twice as high as at the M3 farm which indicated a higher mussel biomass at M2 compared to M3. The lower organic input to the sediment below the M3 farm suggests that the effects of organic matter enrichment such as hypoxia and increased sulfate reduction in the sediment will be lower compared to M2 (Hargrave et al. 2008). Valdermarsen et al. (2009), however, concluded from studies with fish farm waste thresholds that organic enrichment should not be defined in terms of organic input but rather in terms of the metabolic capacity of the sediment. Even so, in the present study, the mussel farm with the lower sedimentation rate showed lower metabolic rates as reflected in lower oxygen consumption rates, lower sulfate reduction rates, and less accumulation of ammonium in the pore water.

$\mathrm{C}: \mathrm{N}$ ratios in suspended material were higher at FS than at REF stations at both M2 and M3, although values were not statistically significant. However, in 


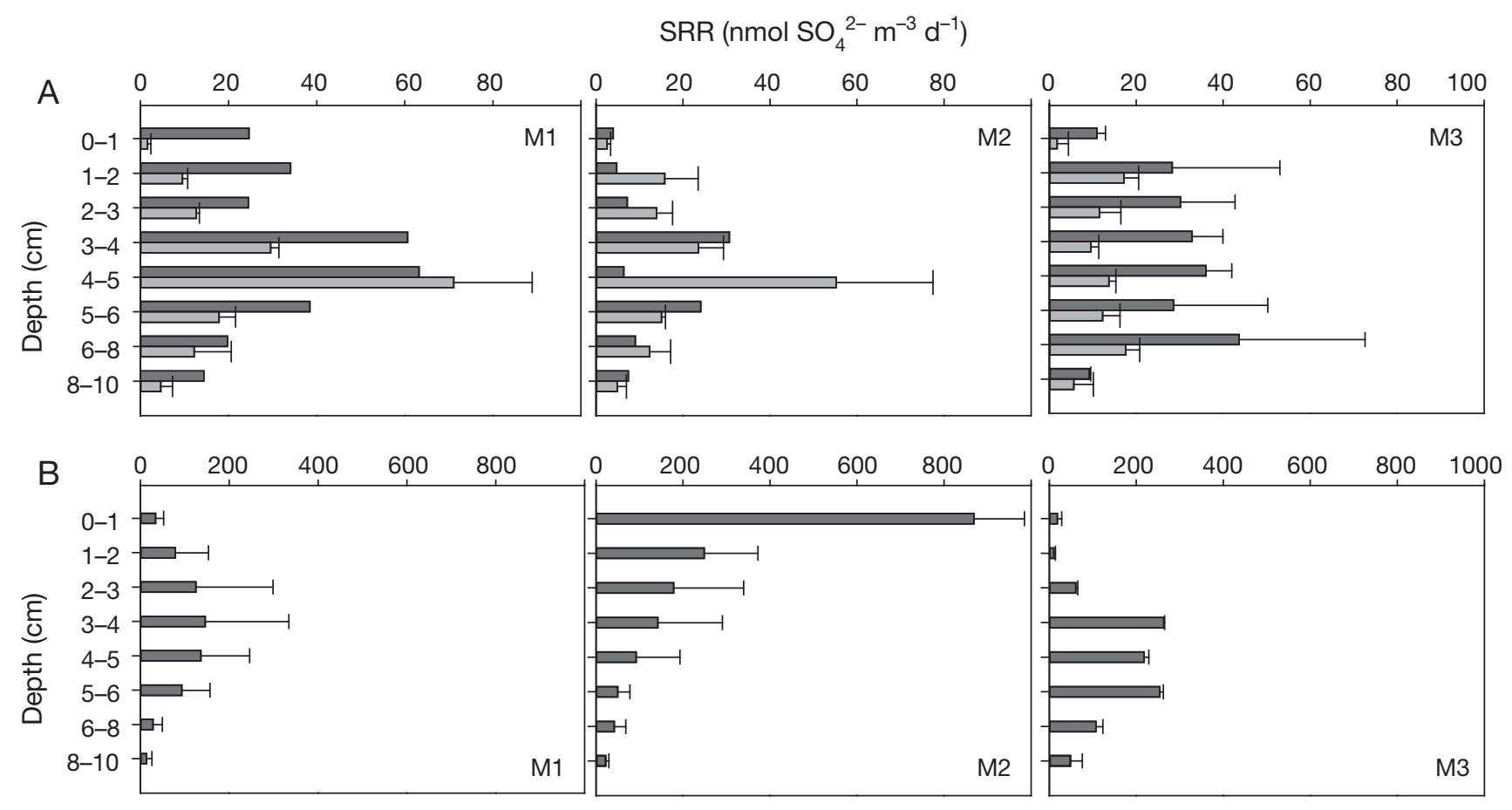

Fig. 5. Depth profile of sulfate reduction rates (SRR) measured at M1, M2 and M3 in May 2005 and May 2006. (A) SRR in May 2005 at FS (dark grey bars), before the mussel farms were established, and in May 2006 at REF (light grey bars). (B) SRR in May 2006 at FS. Data are means of 3 replicates (+SD) or 2 replicates (no SD). Other abbreviations as in Fig. 2

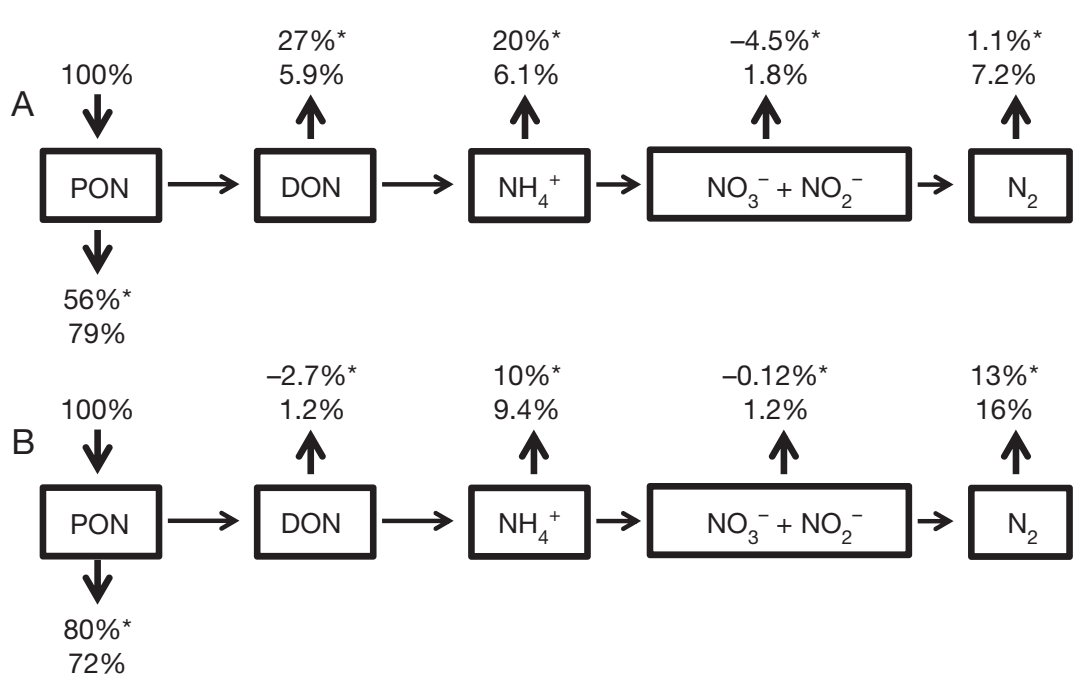

Fig. 6. Relative degradation of suspended PON at FS (*) and REF at (A) M2 and (B) M3. The flux of $\mathrm{DON}, \mathrm{NH}_{4}{ }^{+}$, and $\mathrm{NO}_{3}{ }^{-}+\mathrm{NO}_{2}{ }^{-}$and nitrogen $\left(\mathrm{N}_{2}\right)$ produced through denitrification were calculated by setting the absolute values of PON sedimentation to $100 \%$. Downward pointing arrows refer to the percentage potentially retained in the sediment (see 'Sediment metabolism TOU, $\mathrm{NH}_{4}^{+}$and DON flux'). Abbreviations as in Figs. 2 \& 3

a study of New Zealand mussel farms, C:N ratios in sediment traps below the farms were significantly higher than in material collected in traps $150 \mathrm{~m}$ outside the farms - a pattern attributed to $\mathrm{N}$ incorpora- tion in mussel tissue (Hartstein \& Stevens 2005). The smaller differences reported here could reflect a wellmixed water column which may have prevented $\mathrm{N}$ limitation below the farm sites. Furthermore, mussel farms did not affect the content of POC or PON in the surface sediment as commonly observed before (Grant et al. 1995, da Costa \& Nalesso 2006, Giles et al. 2006). However, RPD and BQI appeared to be sensitive indicators of mussel farm impacts in the sediment.

\section{Impacts on nitrogen cycle}

The increased sedimentation rates observed at mussel farms in the present study were accompanied by increased $\mathrm{NH}_{4}{ }^{+}$efflux from sediment under the mussel lines. The relatively large effect on $\mathrm{NH}_{4}{ }^{+}$release and pore water concentration, especially at M2, suggests stimulated benthic metabolism in which ammonium is released as the end product of organic matter decomposition (Mackin \& Aller 1984). In addition to $\mathrm{NH}_{4}{ }^{+}$, 
DON is also an important source of bioavailable nitrogen, and DON effluxes were in the same range as those of $\mathrm{NH}_{4}{ }^{+}$.

When considering mitigation of $\mathrm{N}$ by mussel farms as a management tool, it is essential to take into account the effect of denitrification. In the present study, sediment denitrification rates exhibited a variable response to organic loading from mussel farms - most likely due to differences in sediment type and farming activities. The reduced sediment at M2 resulted in decreasing Dn at FS, with levels only half of those observed at REF on all sampling occasions. Thus denitrification removed only $\sim 1 \%$ of the total $\mathrm{N}$ sedimentation at FS, which is in the same low range as that found by Christensen et al. (2003) in a New Zealand mussel farm. Sulfide may have inhibited nitrification, and thus also Dn (Joye \& Hollibaugh 1995, Christensen et al. 2003), as well as stimulating dissimilatory nitrate reduction to ammonium (DNRA) (Christensen et al. 2000) as indicated by high $\mathrm{NH}_{4}{ }^{+}$release. Sediment at M3 had a thicker RPD layer and lower sulfate reduction rates in the nitrate reduction zone, which may explain the stimulated Dn at this FS compared to the FS at M2. The biogeochemical responses observed at M1 were similar to those at M3, despite the fact that mussel biomass at M3 appeared lower than at M1, and thus potentially indicated a lower sedimentation rate. But as the sedimentation rate was not measured at M1, it is yet unclear whether factors other than biomass, such as lower food availability, have influenced the sedimentation rate or the sediment below M1 had more efficient metabolic activity (Valdemarsen et al. 2009) with its location in a more exposed area, potentially resulting in a better mixed water column and increased supply of oxygen. M2 was located in a sheltered area with a potentially lower current speed, and the farm therefore had a higher local effect (Ferreira et al. 2007); however, water currents were not measured in the present study. Although Minjeaud et al. (2009) found denitrification to efficiently remove $\mathrm{N}$ from a mussel-cultivating environment in the Mediterranean Sea, investigations examining other organic-rich environments have revealed denitrification to be inhibited below mussel farms in favour of DNRA (Gilbert et al. 1997, Christensen et al. 2003). Nizzoli et al. (2006) observed a large net input of $\mathrm{N}$ to sediments, based on the complete absence of denitrification in favour of DNRA in an Italian lagoon associated with intense shellfish cultivation.

Covering an area of 1 ha, the mussel farm at M2 produced $250 \mathrm{t}$ of mussels over 1 harvest cycle (16 mo) and has the potential of removing $2500 \mathrm{~kg}$
$\mathrm{N}$ through harvest of mussel tissue. $\mathrm{N}$ sedimentation at M2 FS during these 16 mo was enhanced by $\sim 990 \mathrm{~kg}$ compared to the REF station. As only approximately $1 \%$ of this was removed through denitrification, $\sim 980 \mathrm{~kg} \mathrm{~N}(40 \%$ of harvested $\mathrm{N})$ remained in the ecosystem, where it was partly recycled from the sediment to the water column as $\mathrm{NH}_{4}{ }^{+}$, and partly retained in the sediment, where it was sequestered or mineralised on a time scale beyond the scope of our study. At M2 REF, 7.2\% of the $\mathrm{N}$ sedimentation was removed through denitrification; however, $\mathrm{N}$ was not removed through harvest at this station. According to our calculations, the bulk of the remaining $\mathrm{N}$ at both FS and REF was retained in the sediment for potential mineralisation at a later timepoint. The uncertainty of mussel biomass at M3 makes it difficult to calculate how much $\mathrm{N}$ was potentially removed at M3 FS. However, as approximately $25 \%$ of the lines at M3 were empty, we assume a $25 \%$ reduction in mussel biomass (i.e. $200 \mathrm{t}$ ) and estimate that the harvest of all mussels at M3 would remove $2000 \mathrm{~kg} \mathrm{~N}$. Enhanced PON sedimentation during 1 harvest cycle was $576 \mathrm{~kg} \mathrm{~N}$, or $508 \mathrm{~kg}$ when accounting for the stimulated denitrification at FS. Hence, only $26 \%$ of harvested $\mathrm{N}$ at this farm remained in the ecosystem. As the mussels feed only on natural seston and no nutrients are added to culture the mussels, it may be expected that the increased sedimentation rates occurring within the farms are, to some extent, counteracted by reduced sedimentation on a larger scale in areas surrounding the farms (Petersen et al. 2012). However, studies of local hydrography, including water column transport of particles, would be required in order to be able to account for such far field effects. Based on our measurements, harvesting 20 units $\mathrm{yr}^{-1}$ could potentially remove $28 \mathrm{t} \mathrm{N}$, the amount initially required to counteract the input from the Lysekil sewage treatment plant. Establishment of 20 mussel farms of 1 ha (i.e. equal in size to those at M2 and M3) would actually remove 29 to $30 \mathrm{t} \mathrm{N}$. Attention must be paid, however, to the possibly escalating impact on the $\mathrm{N}$ cycle over time. The mussel farms investigated in the present study had been in place for only $1.5 \mathrm{yr}$, and it was clear that the highest increase from REF to FS had occurred during the last sampling occasion. This indicates that the continuous loading of mussel biodeposits gradually increases the demand for oxygen to reoxidize reduced compounds, leading to oxygen depletion and stimulating the production of sulfide (Hargrave et al. 2008). Sampling on a regular basis for a longer time would be beneficial to properly confirm 
this. Consequences of mussel farms on water quality and nitrogen removal have been evaluated before in other eutrophic areas by calculation of $\mathrm{N}$ budgets with sinks (grazing of phytoplankton and uptake of detritus) and sources (excretion from mussels and faeces) (Ferreira et al. 2009). Their study showed that $70 \%$ of the ingested phytoplankton and detritus was removed through mussel harvest in Pertuis Breton, France. Similarly, Nunes et al. (2011) found that negative effects of the farms were small, and local and sediment enrichment was insignificant compared to the net removal and economic gain by mussel harvest. On the other hand, Cranford et al. (2007) predicted that only a small amount of nitrogen was removed through mussel harvest compared to the agricultural input and input from mussel excretion and biodeposition in an East Canadian bay. They found that of the amount of $\mathrm{N}$ defecated from the mussels to the sediment, $63 \%$ was regenerated to the water column as total inorganic $\mathrm{N}$. They also suggested that inhibition of denitrification increased the $\mathrm{N}$ regeneration more than predicted in their model. The present study supports the correlation between elevated TOU, SRRs and nutrient release, and negative effects on benthic RPD and BQI. The measured fluxes, however, correspond to much lower $\mathrm{N}$ regeneration into the water compared to the $\mathrm{N}$ received from the mussels. The contradiction between our study and some of the others may be due to different local hydrodynamic characters and different methods used in the $\mathrm{N}$ budget calculations, as the fluxes in Cranford et al. (2007) were based on models compared to direct measurements in the present study. Furthermore, the denitrification in the present study was generally stimulated by increased $\mathrm{N}$ sedimentation, and, in the end, there was a net removal of $\mathrm{N}$ by the mussel harvest. In addition to the observed $\mathrm{N}$ cycling trends, the significant stimulation of $\mathrm{HPO}_{4}{ }^{2-}$ release indicates that the presence of oxidized iron was low, which is similar to observations in Limfjorden sediments with limited binding capacity of phosphate (Holmer et al. 2003).

Acknowledgements. Financial support for this research was provided by Ekhaga Stiftelse, Birgit och Birger Wåhlströms minnesfond and the Swedish Research Council Formas. The authors thank Sven Kollberg and Lars-Ove Loo for sharing their knowledge of mussel farms and related statistics. We also acknowledge the helpful crew of the RV 'Oscar von Sydow' and Markus Klingberg, while Barry Hargrave is thanked for his valuable comments regarding the manuscript. Four anonymous and constructive reviewers are thanked for helping us improve the manuscript.

\section{LITERATURE CITED}

Anonymous (2001) The Skagerrak - environmental state and monitoring prospects. A popular report. Forum Skagerrak, Göteborg. Available from the Swedish Meteorological and Hydrological Institute (SMHI)

Carlsson MS, Holmer M, Petersen JK (2009) Seasonal and spatial variations of benthic impacts of mussel longline farming in a eutrophic Danish fjord, Limfjorden. J Shellfish Res 28:791-801

Christensen PB, Rysgaard S, Sloth NP, Dalsgaard T, Schwærter S (2000) Sediment mineralization, nutrient fluxes, denitrification and dissimilatory nitrate reduction to ammonium in an estuarine fjord with sea cage trout farms. Aquat Microb Ecol 21:73-84

Christensen PB, Glud RN, Dalsgaard T, Gillespie P (2003) Impacts of longline mussel farming on oxygen and nitrogen dynamics and biological communities of coastal sediments. Aquaculture 218:567-588

$>$ Cranford PJ, Strain PM, Dowd M, Hargrave BT, Grant J, Archambault MC (2007) Influence of mussel aquaculture on nitrogen dynamics in a nutrient enriched coastal embayment. Mar Ecol Prog Ser 347:61-78

da Costa K, Nalesso RC (2006) Effects of mussel farming on macrobenthic community structure in southeastern Brazil. Aquaculture 258:655-663

> Dahlbäck B, Gunnarsson LÅH (1981) Sedimentation and sulfate reduction under a mussel culture. Mar Biol 63: 269-275

> Diaz RJ, Rosenberg R (2008) Spreading dead zones and consequences for marine ecosystems. Science 321:926-929

Edebo L, Haamer J, Lindahl O, Loo LO, Piriz L (2000) Recycling of macronutrients from sea to land using mussel cultivation. Int J Environ Pollut 13:190-207

> Ferreira JG, Hawkins AJS, Bricker SB (2007) Management of productivity, environmental effects and profitability of shell fish aquaculture-the Farm Aquaculture Resource Management (FARM) model. Aquaculture 264:160-174

Ferreira JG, Sequeira A, Hawkins AJS, Newton A and others (2009) Analysis of coastal and offshore aquaculture: application of the FARM model to multiple systems and shellfish species. Aquaculture 289:32-41

Fossing PB, Jørgensen BB (1987) Measurements of bacterial sulfate reduction in sediments: evaluation of a singlestep chromium reduction method. Biogeochemistry 8: 205-222

> Gilbert F, Souchu P, Bianchi M, Bonin P (1997) Influence of shellfish farming activities on nitrification, nitrate reduction to ammonium and denitrification at the watersediment interface of the Thau lagoon, France. Mar Ecol Prog Ser 151:143-153

Giles H, Pilditch CA, Bell DG (2006) Sedimentation from mussel (Perna canaliculus) culture in the Firth of Thames, New Zealand: impacts on sediment oxygen and nutrient fluxes. Aquaculture 261:125-140

Grangeré K, Gangnery A, Bacher C, Ménesguen A (2008) Modelling nitrogen cycle in a small intertidal estuary: respective influence in environmental factors and cultivated oysters. ICES CM 2008/H:04

Grant J, Hatcher A, Scott DB, Pocklington P, Schafer CT, Winters GV (1995) A multidisciplinary approach to evaluating impacts of shellfish aquaculture on benthic communities. Estuaries 18:124-144

Hargrave BT, Holmer M, Newcombe CP (2008) Towards a classification of organic enrichment in marine sediments 
based on biogeochemical indicators. Mar Pollut Bull 56: 810-824

Hartstein ND, Stevens CL (2005) Deposition beneath longline mussel farms. Aquacult Eng 33:192-213

> Holmer M, Ahrensberg N, Jørgensen NP (2003) Impacts of mussel dredging on sediment phosphorus dynamics in a eutrophic Danish fjord. Chem Ecol 19:343-361

Hulth S, Aller RC, Gilbert F (1999) Coupled anoxic nitrification manganese reduction in marine sediments. Geochim Cosmochim Acta 63:49-66

Joye SB, Hollibaugh JT (1995) Influence of sulfide inhibition of nitrification on nitrogen regeneration in sediments. Science 270:623-625

Kaspar HF, Gillespie PA, Boyer IC, MacKenzie LC (1985) Effects of mussel aquaculture on the nitrogen cycle and benthic communities in Kenepuru Sound, Marlborough Sounds, New Zealand. Mar Biol 85:127-136

Kautsky N, Evans S (1987) Role of biodeposition by Mytilus edulis in the circulation of matter and nutrients in a Baltic coastal ecosystem. Mar Ecol Prog Ser 38:201-212

Laursen AE, Seitzinger SP (2002) The role of denitrification in nitrogen removal and carbon mineralization in midAtlantic Bight sediments. Cont Shelf Res 22:1397-1416

Lindahl L, Kollberg S (2009) Can the EU agri-environmental aid program be extended into the coastal zone to combat eutrophication? Hydrobiologia 629:59-64

Lindahl O, Hart R, Henroth B, Kollberg S and others (2005) Improving marine water quality by mussel farming: a profitable solution for Swedish society. Ambio 34: 131-138

Mackin JE, Aller RC (1984) Ammonium adsorption in marine sediments. Limnol Oceanogr 29:250-257

Martens CS, Berner RA (1974) Methane production in the interstitial waters of sulphate-depleted marine sediments. Science 185:1167-1169

Minjeaud L, Michotey VD, Garcia N, Bonin PC (2009) Seasonal variation in di-nitrogen fluxes and associated processes (denitrification, anammox and nitrogen fixation) in sediment subject to shellfish farming influences. Aquat Sci 71:425-435

Nielsen LP (1992) Denitrification in sediment determined from nitrogen isotope paring. FEMS Microbiol Ecol 86: 357-362

Nilsson HC, Rosenberg R (1997) Benthic habitat quality assessment of an oxygen stressed fjord by surface and sediment profile images. J Mar Syst 11:249-264

Nizzoli D, Welsh DT, Fano EA, Viaroli P (2006) Impact of

Editorial responsibility: Jonathan Grant,

Halifax, Nova Scotia, Canada clam and mussel farming on benthic metabolism and nitrogen cycling, with emphasis on nitrate reduction pathways. Mar Ecol Prog Ser 315:151-165

> Nunes JP, Ferreira JG, Bricker SB, O'Loan B and others (2011) Towards an ecosystem approach to aquaculture: assessment of sustainable shellfish cultivation at different scale of space, time and complexity. Aquaculture 315:369-383

Pearson TH, Rosenberg R (1976) A comparative study of the effects on the marine environment of wastes from cellulose industries in Scotland and Sweden. Ambio 5: 77-79

Petersen JK, Loo LO (2004) Miljøkonsekvenser af dyrkning af blåmuslinger (Danish report). In: Rapport til Interreg IIIA projektet: 'Blåskjellanlegg og kvoteordning'. Pub. No. 114473, University of Gothenburg, p 1-42

Petersen JK, Timmermann K, Carlsson MS, Holmer M, Maar M, Lindahl O (2012) Mussel farming can be used as mitigation tool-a reply. Mar Pollut Bull 64:452-454

> Risgaard-Petersen N, Nielsen LP, Rysgaard S, Dalsgaard T, Meyer RL (2004) Application of the isotope pairing technique in sediments where anammox and denitrification coexist. Limnol Oceanogr Methods 2:315-315

Rosenberg R (1990) Negative oxygen trends in Swedish coastal bottom waters. Mar Pollut Bull 21:335-339

Sayama M (2001) Presence of nitrate-accumulating sulfur bacteria and their influence on nitrogen cycling in a shallow coastal marine sediment. Appl Environ Microbiol 67 : 3481-3487

Smaal AC (2002) European mussel cultivation along the Atlantic coast: production status, problems and perspectives. Hydrobiologia 484:89-98

Strickland JDH, Parsons TR (1972) A practical handbook of sea water analysis. Bull Fish Res Board Can Bull 169: $1-311$

Thamdrup B, Dalsgaard T (2002) Production of $\mathrm{N}_{2}$ through anaerobic ammonium oxidation coupled to nitrate reduction in marine sediments. Appl Environ Microbiol 68: 1312-1318

> Trimmer M, Nicholls JC, Morley N, Davies CA, Aldridge J (2005) Biphasic behavior of anammox regulated by nitrite and nitrate in an estuarine sediment. Appl Environ Microbiol 71:1923-1930

Valdemarsen T, Kristensen E, Holmer M (2009) Metabolic threshold and sulfide buffering in diffusion controlled marine sediments impacted by continuous organic enrichment. Biogeochemistry 95:335-353

Submitted: June 6, 2011; Accepted: February 9, 2012 Proofs received from author(s): March 16, 2012 